\title{
Study of Orchid Resistance from Ceratorhiza sp. Induction Against ORSV Infection Based on Root Anatomy Character
}

\author{
Ketut Lestari, Sri Wahyuningsih, Mahfut ${ }^{*}$, Tundjung Tripeni Handayani \\ Program Studi Biologi, Fakultas Matematika dan Ilmu Pengetahuan Alam, Universitas Lampung, Bandar Lampung \\ 35144, Indonesia \\ *Corresponding author: mahfut.mipa@ fmipa.unila.ac.id
}

\begin{abstract}
Indonesia is the country that has the largest wealth of orchid germ plasma in the world. Some popular types of orchids are Phalaenopsis amabilis and Dendrobium discolor. However, efforts to plant orchids are often hampered by viral attacks, one of which is the Odontoglossum ringpot virus (ORSV). Effective virus control on orchids can be done by using mycorrhiza, one of which is Ceratorhiza. This study aimed to determine differences in the anatomical character of the roots of Phalaenopsis amabilis and Dendrobium discolor, and efficacy of Ceratorhiza sp. in encouraging orchids to overcome ORSV infection. The design used in this study was a factorial randomized design (CRD) with 6 treatments and 4 iterations. Root anatomical observations were performed by making root cross -sections stained with phloroglucin (for lignin observation) and methylene blue staining (for peloton treatment), then observed using a microscope. The results showed that Ceratorhiza sp. in Phalaenopsis amabilis and Dendrobium discolor, the thickness of lignin in the epidermis and carrier bundles was thicker than that of treatment given only for viruses and mycorrhizal viruses.
\end{abstract}

Keywords: Ceratorhiza sp., Dendrobium discolor, ORSV, Phalaenopsis amabilis

\section{ABSTRAK}

Indonesia merupakan negara yang menyimpan kekayaan plasma nutfah anggrek paling besar di dunia. Beberapa jenis anggrek yang populer yaitu Dendrobium dan Phalaenopsis. Namun upaya pembudidayaan anggrek seringkali terhambat oleh adanya serangan virus, salah satunya adalah Odontoglossum ringspot virus (ORSV). Pengendalian virus yang efisien pada tanaman anggrek dapat dilakukan dengan memanfaatkan mikoriza, salah satunya yaitu Ceratorhiza. Penelitian ini bertujuan untuk mengetahui perbedaan karakter anatomi akar Phalaenopsis amabilis dan Dendrobium discolor, serta mengetahui keefektifan Ceratorhiza sp. dalam menginduksi anggrek untuk mengatasi infeksi ORSV. Rancangan yang digunakan pada penelitian ini yaitu Rancangan Acak Lengkap (RAL) faktorial dengan 6 perlakuan dan 4 ulangan. Pengamatan anatomi akar dilakukan dengan membuat preparat irisan melintang akar yang diberi pewarnaan phloroglucin (untuk pengamatan lignin) dan pewarnaan methylen blue (untuk pengamatan peloton), kemudian diamati menggunakan mikroskop. Hasil penelitian menunjukkan bahwa Induksi Ceratorhiza sp. pada Phalaenopsis amabilis dan Dendrobium discolor menyebabkan ketebalan lignin pada epidermis dan berkas pengangkut lebih tebal dibanding perlakuan yang hanya diberi virus dan mikoriza virus.

Kata Kunci : Ceratorhiza sp., Dendrobium discolor, ORSV, Phalaenopsis amabilis 


\section{PENDAHULUAN}

Anggrek merupakan tanaman hias yang sangat prospektif dengan bentuk dan warna bunga yang menarik sehingga mempunyai nilai ekonomis tinggi [5]. Beberapa jenis anggrek yang banyak diminati dan dibudidayakan oleh berbagai kalangan yaitu Phalaenopsis sp. dan Dendrobium sp. [5;6]. Salah satu upaya pelestarian tanaman anggrek yaitu dengan melakukan budidaya, namun upaya pembudidayaan anggrek seringkali terhambat oleh adanya serangan penyakit, salah satunya adalah Odontoglossum ringspot virus (ORSV) [9].

Pengendalian penyakit pada tanaman anggrek dapat dilakukan dengan memanfaatkan mikoriza yang hidup berasosiasi dengan perakaran tanaman anggrek. Pada anggrek, mikoriza bermanfaat untuk perkecambahan biji, meningkatkan pertumbuhan anggrek, dan melindungi anggrek dari serangan patogen $[1 ; 6]$.

Beberapa penelitian sebelumnya telah melaporkan bahwa inokulasi Ceratorhiza memberi efek lebih pada jumlah akar yang mati pada minggu ke-1 dan ke-2. Kemudian pada minggu ke-3 dan ke-4 muncul sejumlah akar baru. Dari minggu ke-4, jumlah rata rata akar yang mati menurun dan jumlah akar hidup meningkat. Hasil penelitian juga menunjukkan bahwa waktu inokulasi terbaik untuk Ceratorhiza adalah hari ke-3 dan ke-4 ([5].

Khaterine dan Kasiamdari [4] dalam hasil penelitiannya menyatakan bahwa Ceratorhiza sp. memiliki potensi secara in vitro mampu menghambat pertumbuhan $F$. oxysporum. Perhitungan persentase penghambatan pertumbuhan dilakukan pada saat pertumbuhan $F$. oxysporum pada kontrol, telah mencapai tepi cawan petri atau pada hari ke-12 setelah inokulasi. Persentase penghambatan oleh Ceratorhiza sp. sebesar 67,70\%.

Berdasarkan uraian di atas dan mengingat pentingnya pemanfaatan jamur mikoriza anggrek dalam mengurangi tingkat keparahan infeksi pada akar anggrek akibat virus maka diperlukan penelitian tentang kajian ketahanan anggrek hasil induksi Ceratorhiza terhadap infeksi ORSV berdasarkan karakter anatomi akar. Tujuan penelitian ini yaitu untuk
Mengetahui perbedaan antara karakter anatomi akar Phalaenopsis amabilis dengan Dendrobium discolor hasil induksi Ceratorhiza sp. yang diinfeksi ORSV dan mengetahui keefektifan Ceratorhiza sp. dalam menginduksi Phalaenopsis amabilis dan Dendrobium discolor untuk mengatasi infeksi ORSV.

\section{METODE}

\section{Alat dan Bahan Penelitian}

Alat yang digunakan dalam penelitian ini yaitu pot kecil, hot plate, neraca, magnetic stirrer, labu ukur, autoclave, pinset, cawan petri, kertas label, mikroskop, lensa optilab, cover dan object glass, pipet tetes, tisu, dan kamera dan bahan yang digunakan adalah bibit anggrek Phalaenopsis amabilis botolan, bibit anggrek Dendrobium discolor botolan, media moss steril, medium Potato Dextrose Agar (PDA) bubuk, mikoriza Ceratorhiza sp., inokulum ORSV, karborundum, buffer phospat, air, alkohol, pewarna phloroglucin, dan larutan $\mathrm{HCl}$.

\section{Rancangan Penelitian}

Rancangan penelitian ini disusun berdasarkan pola Rancangan Acak Lengkap (RAL) dengan 2 faktor perlakuan. Faktor 1 adalah jenis anggrek dan faktor 2 adalah jenis perlakuan, sehingga diperoleh kombinasi perlakuan seperti yang ditampilkan pada Tabel 1.

Tabel 1. Kombinasi Perlakuan

\begin{tabular}{|c|c|c|c|}
\hline$F 1 \quad F 2$ & $\mathbf{M}$ & V & MV \\
\hline$\overline{A_{1}}$ & $\mathrm{~A}_{1} \mathrm{M}$ & $\mathrm{A}_{1} \mathrm{~V}$ & $\mathrm{~A}_{1} \mathrm{MV}$ \\
\hline $\mathbf{A}_{2}$ & $\mathrm{~A}_{2} \mathrm{M}$ & $\mathrm{A}_{2} \mathrm{~V}$ & $\mathrm{~A}_{2} \mathrm{MV}$ \\
\hline
\end{tabular}

Keterangan:

$\begin{array}{ll}\mathrm{A}_{1} & : \text { Phalaenopsis amabilis } \\ \mathrm{A}_{2} & \text { : Dendrobium discolor } \\ \mathrm{M} & : \text { Ceratorhiza } \mathrm{sp} . \\ \mathrm{V} & \text { : Odontoglossum ringspot virus (ORSV) }\end{array}$

Penelitian ini menggunakan 6 kombinasi perlakuan dan dilakukan sebanyak 4 kali ulangan $\left(\mathrm{U}_{1}, \mathrm{U}_{2}, \mathrm{U}_{3}\right.$, dan $\left.\mathrm{U}_{4}\right)$ sehingga diperoleh 24 satuan percobaan. Sebagai faktor 
pembanding, digunakan kontrol berupa tanaman anggrek yang tidak diberi perlakuan.

\section{Tahapan Penelitian}

1) Aklimatisasi Anggrek: Bibit anggrek botolan dikeluarkan dari botol dan ditanam pada media Spaghnum dalam pot-pot kecil.

2) Persiapan Medium Inokulasi Mikoriza: Medium yang digunakan adalah Potato Dextrose Agar (PDA). Pembuatan medium PDA dilakukan dengan cara melarutkan 39 gram medium PDA bubuk dalam 1 liter aquadest, kemudian dihomogenkan dengan hot plate dan magnetic stirrer. Setalah homogen, medium dituang ke Erlenmeyer dan dilakukan sterilisasi pada autoklaf. Metode inokulasi Ceratorhiza sp. dilakukan dengan menggunakan metode Nuangmek et al. [7], yaitu Ceratorhiza sp. diinokulasi pada medium PDA dan diinkubasi selama 7 hari.

3) Inokulasi Mikoriza: Anggrek diletakkan pada cawan petri yang berisi inokulum Ceratorhiza sp. Keberhasilan inokulasi dapat dilihat dari terbentuknya struktur peloton (lilitan padat) oleh Ceratorhiza sp. pada bagian akar anggrek.

4) Inokulasi virus: Inokulasi virus dilakukan dengan terlebih dahulu menaburkan karborundum pada permukaan atas daun anggrek. Kemudian inokulum ORSV digerus dan ditambahkan buffer fosfat dengan perbandingan 1:10 $(\mathrm{m} / \mathrm{v})$. Inokulum ORSV ini kemudian dituang pada daun dengan karborundum pada permukaan atasnya. Karborundum digeser agar terjadi pelukaan mekanis pada daun sehingga memudahkan penetrasi virus. Inokulasi dilakukan searah dengan pertulangan daun.

5) Pengamatan anatomi: Pengamatan anatomi akar dilakukan dengan membuat preparat irisan melintang akar yang diberi pewarnaan phloroglucin (untuk pengamatan lignin), kemudian diamati menggunakan mikroskop dengan perbesaran $4 \times 10 \mu \mathrm{m}$.

\section{Pengamatan Variabel}

Pengamatan lignifikasi pada irisan melintang akar planlet anggrek menggunakan metode Ruzin [2]. Akar anggrek dipotong secara melintang menggunakan silet. Potongan irisan melintang diletakkan di atas gelas preparat kemudian diberi pewarna phloroglucin dan dikering-anginkan. Sesudah kering, gelas preparat ditutup dengan gelas penutup. Selanjutnya gelas preparat diamati di bawah mikroskop dengan perbesaran 40, 100 dan 400x. Jaringan akar yang terlignifikasi akan tampak berwarna merah keunguan. Pengaruh perlakuan mikoriza, virus dan mikoriza virus, selanjutnya dideteksi efeknya antara lain melalui pengukuran ketebalan lignin pada jaringan akar. Pengukuran ketebalan lignin dengan menggunakan mikrometer okuler.

\section{HASIL}

Hasil pengamatan akar anggrek Phalaenopsis amabilis dan Dendrobium discolor sayatan melintang pada masing-masing perlakuan diperoleh data lignifikasi yang disajikan pada Tabel 2 .

Hasil pengamatan sayatan melintang akar anggrek menunjukan bagian epidermis dan berkas pengangkut berwarna merah muda keunguan seperti pada Gambar 1 dan 2. Hal tersebut mengindentifikasikan adanya penebalan dinding sel (lignifikasi).

Tabel 2. Ketebalan lignin pada akar Phalaenopsis amabilis dan Dendrobium discolor

\begin{tabular}{cccc}
\hline Jenis Anggrek & Perlakuan & Epidermis $(\boldsymbol{\mu m})$ & Berkas pengangkut $(\boldsymbol{\mu m})$ \\
\hline $\mathrm{A}_{1}$ & $\mathrm{M}$ & 20,15 & 31,07 \\
(Phalaenopsis & $\mathrm{V}$ & 19,31 & 24,96 \\
amabilis) & $\mathrm{MV}$ & 16,23 & 12,63 \\
& $\mathrm{~K}$ & 31,23 & 33,48 \\
\hline $\mathrm{A}_{2}$ & $\mathrm{M}$ & 27,89 & 6,87 \\
(Dendrobium & $\mathrm{V}$ & 23,30 & 11,78 \\
discolor) & $\mathrm{MV}$ & 26,56 & 0 \\
& $\mathrm{~K}$ & 25,81 & 21,51 \\
\hline
\end{tabular}




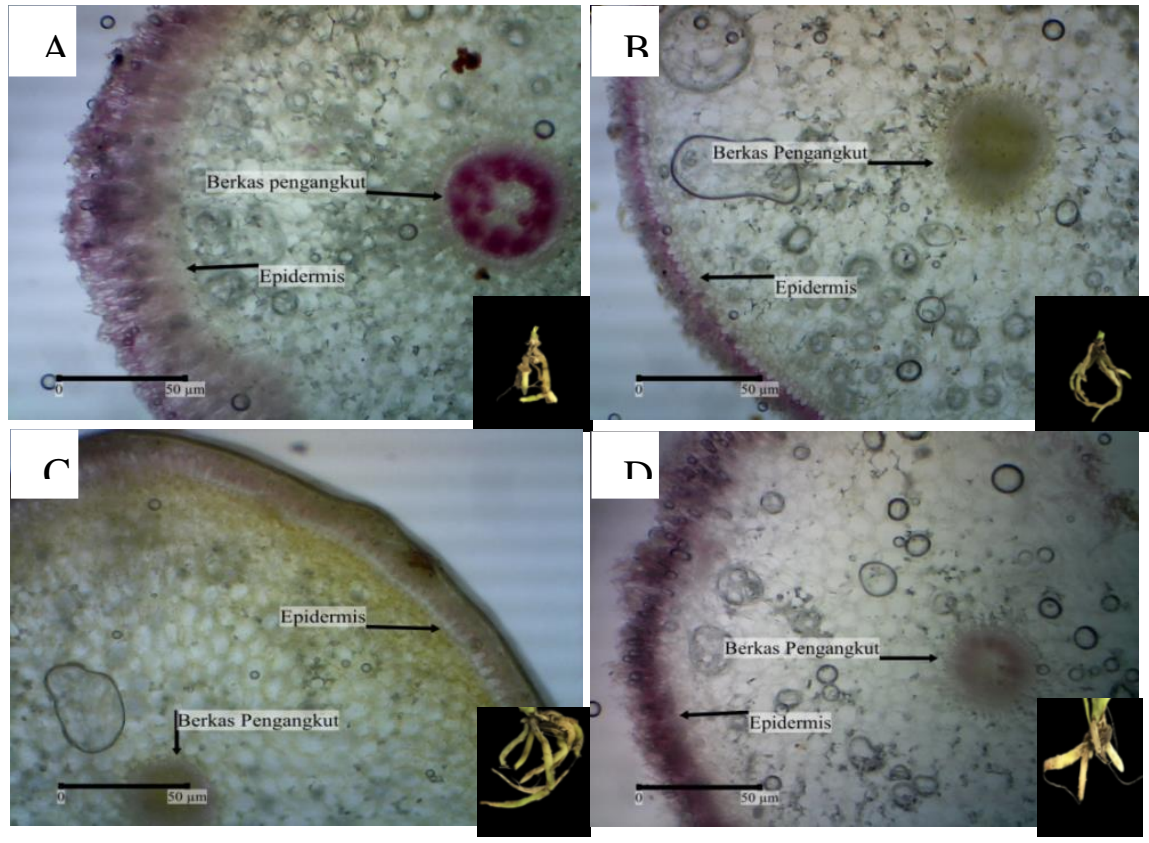

Gambar 1. Penampang Melintang akar Phalaenopsis amabilis $\left(\mathrm{A}_{1}\right)$. Keterangan: A) KA1 (kontrol), B) M1A1 (perlakuan mikoriza), C) A1V (perlakuan virus), D) M1A1V (perlakuan mikoriza virus). Perbesaran 40x, Bar: $50 \mu \mathrm{m}$.

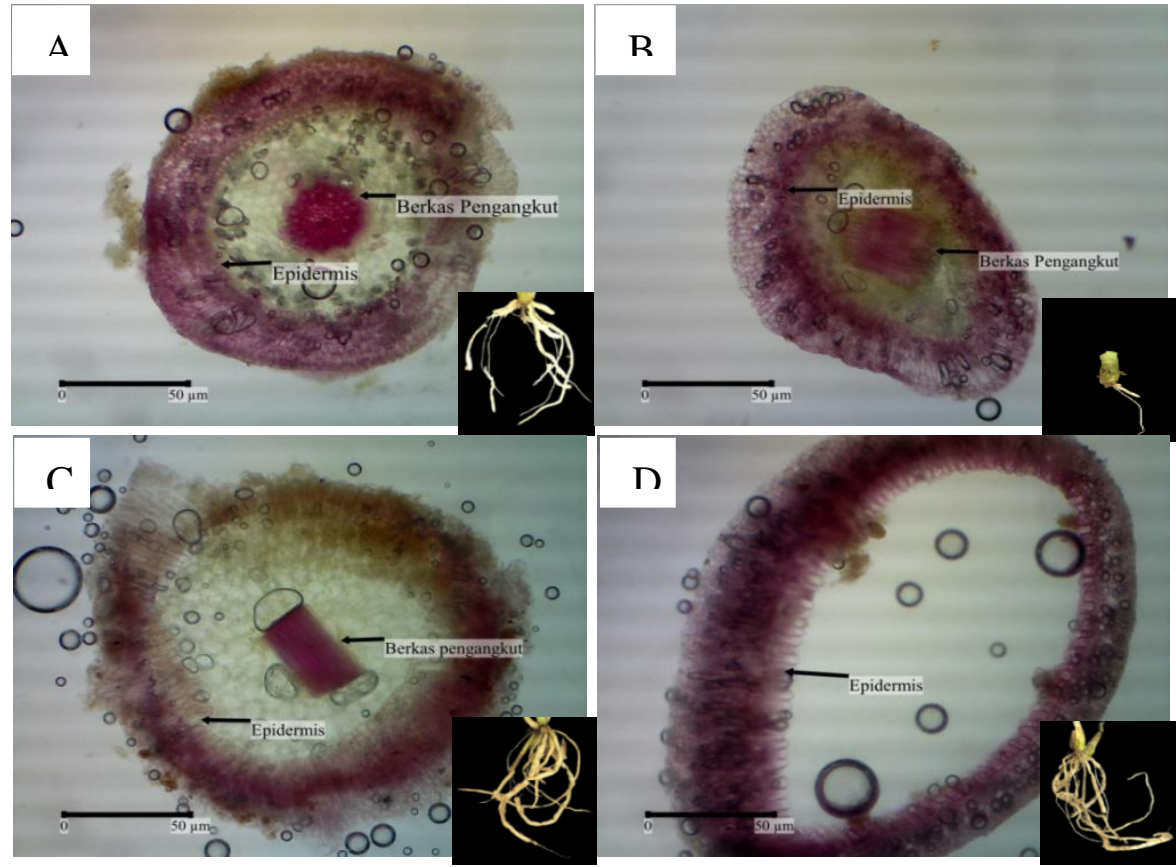

Gambar 2. Penampang Melintang akar Dendrobium discolor $\left(\mathrm{A}_{2}\right)$. Keterangan : A) KA2 (kontrol), B) M1A2 (perlakuan mikoriza), C) A2V (perlakuan virus), D) M1 A2V (perlakuan mikoriza virus). Perbesaran 40x Bar: $50 \mu m$. 


\section{PEMBAHASAN}

Hasil induksi Ceratorhiza sp. pada Phalaenopsis amabilis dan Dendrobium discolor menunjukkan adanya penebalan dinding sel (lignifikasi). Apabila dibandingkan ketebalanan lignin pada Phalaenopsis amabilis dengan Dendrobium discolor pada semua perlakuan yang diberi mikoriza, virus maupun mikoriza virus lignin pada jaringan epidermis akar Dendrobium discolor lebih tebal dibandingkan lignin pada jaringan epidermis Phalaenopsis amabilis. Pada perlakuan mikoriza tebal lignin pada epidermis Dendrobium discolor berkisar 27,89 $\mu \mathrm{m}$ sedangkan pada Phalaenopsis amabilis berkisar 20,15 $\mu \mathrm{m}$. Pada perlakuan virus tebal lignin pada epidermis Dendrobium discolor berkisar 23,30 $\mu \mathrm{m}$ sedangkan pada Phalaenopsis amabilis berkisar 19,31 $\mu \mathrm{m}$. Pada perlakuan mikoriza virus tebal lignin pada epidermis Dendrobium discolor berkisar 27,89 $\mu \mathrm{m}$ sedangkan pada Phalaenopsis amabilis berkisar 20,15 $\mu \mathrm{m}$. Pada kontrol tebal lignin pada epidermis Dendrobium discolor berkisar 25,81 $\mu \mathrm{m}$ sedangkan pada Phalaenopsis amabilis berkisar $31,23 \mu \mathrm{m}$. Hal ini menunjukkan bahwa tebal lignin jaringan epidermis disemua perlakuan pada Phalaenopsis amabilis tidak lebih tebal dibandingkan dengan kontrol dan pada Dendrobium discolor, perlakuan yang diberi virus tidak lebih tebal apabila dibandingkan kontrol namun pada perlakuan yang diberi mikoriza dan mikoriza virus lebih tebal dibandingkan kontrol.

Berbeda dengan ketebalan lignin bagian epidermis, ketebalan lignin dibagian berkas pengangkut pada Phalaenopsis amabilis dengan dendrobium discolor apabila dibandingkan jauh lebih tebal pada Phalaenopsis amabilis disetiap perlakuan. Pada perlakuan mikoriza tebal lignin pada berkas pengangkut Phalaenopsis amabilis berkisar 31,07 $\mu \mathrm{m}$ sedangkan pada Dendrobium discolor berkisar $6,87 \mu \mathrm{m}$. Pada perlakuan virus tebal lignin pada berkas pengangkut Phalaenopsis amabilis berkisar 24,96 $\mu \mathrm{m}$ sedangkan pada Dendrobium discolor berkisar $11,78 \mu \mathrm{m}$. Pada perlakuan mikoriza virus tebal lignin pada berkas pengangkut Phalaenopsis amabilis berkisar 12,63 $\mu \mathrm{m}$ sedangkan pada Dendrobium discolor tidak terdapat lignin. Pada kontrol tebal lignin pada berkas pengangkut Phalaenopsis amabilis berkisar 33,48 $\mu \mathrm{m}$ sedangkan pada Dendrobium discolor berkisar 21,51 $\mu \mathrm{m}$. Hal ini menunjukkan bahwa tebal lignin berkas pengangkut di setiap perlakuan pada Phalaenopsis amabilis dan Dendrobium discolor tidak lebih tebal apabila dibandingkan dengan kontrol.

Sayatan melintang akar kontrol pada anggrek Phalaenopsis amabilis dan Dendrobium discolor memiliki lignin pada epidermis dan jaringan pengangkut. Hal ini disebabkan karena adanya sel velamen yang memiliki suberin dan penebalan dinding pada bagian epidermis yang berfungsi agar mengurangi penguapan air pada akar. Pada berkas pengangkut juga sudah ada lignin yang berfungsi untuk melindungi penguapan air pada saat transportasi unsur hara dan hasil fotosintesis [8]. Oleh sebab itu, maka hasil lignifikasi setiap perlakuan yaitu $\mathrm{M}, \mathrm{V}$, dan MV dibandingkan dengan kontrol pada masing masing anggrek.

Ketebalan lignin pada jaringan epidermis dan berkas pengangkut akar Phalaenopsis amabilis pada perlakuan mikoriza, virus maupun mikoriza virus tidak lebih tebal dibandingkan dengan kontrol. Hal ini diduga karena induksi Ceratorhiza sp. kurang efektif dalam memicu terbentuknya lignin pada Phalaenopsis amabilis. Lignifikasi pada akar Dendrobium discolor berbeda dengan Phalaenopsis amabilis, pada akar pada Dendrobium discolor pada perlakuan M dan MV mengalami lignifikasi epidermis yang lebih tebal dibandingkan dengan kontrol. Apabila dibandingkan antara Phalaenopsis amabilis dengan Dendrobium discolor terbentuknya lignin di jaringan epidermis lebih tebal pada Dendrobium discolor. Akan tetapi ketebalan lignin pada berkas pengangkut lebih tebal pada Phalaenopsis amabilis dibanding Dendrobium discolor, hal ini diduga lignin pada berkas pengangkut Phalaenopsis amabilis lebih tebal karena berfungsi menyalurkan hasil fotosintesis ke jaringan tumbuhan, sehingga tanaman anggrek Phalaenopsis amabilis memiliki akar dan daun yang lebih tebal [2].

Pada akar anggrek yang diberi perlakuan mikoriza dan mikoriza virus terbentuk lignin yang lebih tebal dibanding perlakuan yang hanya diberi virus saja. Hal ini diduga akibat ada serangan patogen yaitu ORSV sehingga anggrek 
membentuk enzim peroksidase untuk melindunginya dan diduga ada induksi dari Ceratorhiza sp. yang juga memicu anggrek meningkatkan aktivitas enzim peroksidase sehingga anggrek menjadi semakin kuat. Enzim peroksidase adalah enzim yang mengkatalis reaksi oksidasi hydrogen peroksida dengan monomer-monomer lignin seperti r-kumaril alkohol, koniferil alkohol, dan sinapsis alkohol menjadi polimer berupa lignin. Dengan keberadaan lignin maka dinding sel tumbuhan menjadi lebih tebal sehingga sulit ditembus oleh vektor [3].

Perpaduan antara mikoriza dan virus menghasilkan lignifikasi epidermis dan lignifikasi berkas pengangkut lebih tebal dibandingkan dengan perlakuan yang hanya diberi virus. Hal ini didukung oleh hasil penelitian Nurfadilah et al. [8] bahwa anggrek yang diinduksi mikoriza mampu meingkatkan aktivitas peroksidase dan memacu terjadinya lignifikasi pada akar anggrek Spathoglotis plicata.

\section{KESIMPULAN}

Induksi Ceratorhiza sp. pada Phalaenopsis amabilis dan Dendrobium discolor menyebabkan ketebalan lignin pada epidermis dan berkas pengangkut lebih tebal dibanding perlakuan yang hanya diberi virus dan mikoriza virus.

\section{DAFTAR PUSTAKA}

[1] Dearnaley, J. Further advances in orchid mycorrhizal research. Mycorrhiza. 2007; 17(6): 475-486.

[2] Frasiandini, I. Struktur anatomi; Struktur Morfologi dan Anatomi Sryngodium isoetifolium. Lentera Bio. 2012; 1: 67-74.

[3] Hopkins, D.W., Webster, E.A., Chudek, J.A., Halpin, C. Decomposition in Soil of Tobacco Plants with Genetic Modifications to Lignin Biosynthesis. Soil Biology and Biochemistry. 2001; 33: 1455-1462.

[4] Khaterine, Kasiamdari, R.S. Identifikasi dan Uji Patogenitas Fusarium sp. Penyebab Penyakit Busuk Pucuk pada Tanaman Anggrek Bulan (Phalaenopsis sp.).
Prosiding Seminar Nasional Pendidikan Biologi. 21 Maret 2015. Malang: Pendidikan Biologi FMIPA Universitas Muhammadiyah Malang.

[5] Mahfut. Indonesia Darurat Konservasi: Sudah Amankah Kebun Raya Kita? Prosiding Seminar Nasional Biodiversitas. Makassar: 20 Agustus 2019.

[6] Mursidawati, S. Asosiasi Mikoriza Dalam Konservasi Anggrek Alam. Buletin Kebun Raya. 2007; 10(1): 21-24.

[7] Nuangmek, W., Mc Kenzie, E.H.C., Lumyong, S. Endophytic Fungi Form Wild Banana (Musa acuminate Colla) Works Against Anthracnose Disease caused by Colletothricum musae. Academic journal inc. Journal of Microbiology. 2008; 3(5): $368-374$.

[8] Nurfadilah, S., Swarts, N.D., Dixon, K.W., Lambers, H., Merritt, D.J. Variation in nutrient- acquisition patterns by mycorrhizal fungi of rare and common orchids explains diversification in a global biodiversity hotspot. Ann Bot. 2016; 111 (6): 1233-1241.

[9] Zettler, F.W., Ko, N.J., Wisler, G.C., Elliot, M.S., Wong, S.M. Viruses of orchids and their kontrol. Plant Dis. 1990; 74:621-626. DOI: https://doi.org/10.1094/PD-74-0621. 